\title{
KORELASI ANTARA EKSPRESI Her-2 DAN Ki-67 DENGAN GLEASON GRADE GROUP PADA ADENOKARSINOMA ASINAR PROSTAT
}

\author{
Putri Ajeng Ayu Larasati ${ }^{1}$, Vega Karlowee ${ }^{2}$, Siti Amarwati ${ }^{2}$, Hermawan Istiadi ${ }^{2}$, Ika Pawitra \\ Miranti $^{2}$ \\ ${ }^{1}$ Residen. Departemen Patologi Anatomik, Fakultas Kedokteran, Universitas Diponegoro/ RSUP \\ Dr.Kariadi \\ ${ }^{2}$ Staf pengajar. Departemen Patologi Anatomik, Fakultas Kedokteran, Universitas Diponegoro/ RSUP \\ Dr.Kariadi \\ Semarang Indonesia
}

Corresponding email: putriajeng.ayularasati@yahoo.com

\begin{abstract}
Abstrak
Latar Belakang : Menurut Database GLOBOCAN 2012, kanker prostat merupakan penyebab utama kelima kematian pada pria.(1) Pemahaman tentang peran onkogen dan tumor suppressor genes mendominasi penelitian tentang biologi kanker saat ini dan berpotensi menghasilkan target terapi kanker terbaru. Salah satu perannya pada adenokarsinoma prostat yang masih belum jelas ialah Her2 dan Ki-67. Perbedaan ekspresi profil molekular Her-2 dan Ki-67 yang diklasifikasikan berdasarkan Gleason grading system terbaru yaitu Grade group diharapkan membantu penentuan prognosis dan manajemen terapi penyakit pada kanker prostat.

Tujuan : Tujuan dari penelitian ini adalah untuk mengetahui korelasi antara ekspresi Her-2 dan Ki-67 dengan Gleason Grade group adenokarsinoma asinar prostat.

Metode: Merupakan penelitian observatif analitik dengan desain cross-sectional menggunakan 31 blok parafin yang terfiksasi formalin dari laboratorium Patologi Anatomik RSUP dr. Kariadi, dengan diagnosis adenokarsinoma asinar prostat kemudian diklasifikasikan menurut kelompok prognostik WHO / ISUP Gleason (Gleason Grade group 1 - 5). Pemeriksaan imunohistokimia dilakukan dengan menggunakan antibodi Her-2 dan Ki-67. Analisa hasil menggunakan uji Spearmans dan uji Kruskal Wallis

Hasil : 31 kasus yang termasuk dalam kriteria inklusi pada penelitian ini, hampir separuhnya (41.94\%) termasuk ke dalam Gleason grade group 5 . Ekspresi Her-2 positif $(+1,+2,+3)$ hampir didapatkan pada seluruh sampel $(90,22 \%)$, dengan Her-2 +3 sebagian besar didapatkan pada grade group 5 $(71,43 \%)$. Ekspresi Ki-67 positif $(+1,+2,+3)$ didapatkan pada seluruh sampel, dengan Ki-67 $+3(>5 \%)$ pada Gleason grade group 5 didapatkan sejumlah 5 sampel (38,46\%). Pada analisa data dengan uji Spearmans disimpulkan bahwa terdapat korelasi positif antara ekspresi Her-2 dan Ki-67 dengan Gleason Grade group. Pada uji Kruskal Wallis didapatkan perbedaan bermakna antara ekspresi Ki-67 dengan Gleason Grade group.

Kesimpulan: Analisa ekspresi Her-2 dan Ki-67 melalui pemeriksaan imunohistokimia dengan klasifikasi terbaru Gleason Grade group dapat menjadi salah satu parameter prognosis dan manajemen terapi pada adenokarsinoma asinar prostat.
\end{abstract}

Kata kunci : Adenokarsinoma asinar prostat, Her-2, Ki-67, Gleason Grade group 


\begin{abstract}
Background: According to the GLOBOCAN Database 2012, prostate cancer is the fifth leading cause of death in men.(1) An understanding of the role of oncogenes and tumor suppressor genes dominates current research on cancer biology and has the potential to produce the latest cancer therapy targets. Biomarker in prostate acinar adenocarcinoma which is still unclear is Her-2 and Ki-67. Differences in the expression of the Her-2 and Ki-67 molecular profiles which are classified based on the latest Gleason grading system namely Grade group are expected to help determine the prognosis and management of therapy in prostate cancer.

Objective: The aim of this study was to determine the correlation between the expression of Her-2 and Ki-67 with Gleason Grade prostate acinar adenocarcinoma group.

Methods: An analytic observational study with cross-sectional design using 31 formalin fixed paraffin embedded from the Anatomical Pathology Laboratory of RSUP dr. Kariadi, with a diagnosis of prostate acinar adenocarcinoma, was classified according to the WHO / ISUP Gleason using Her-2 and Ki-67 antibodies. Analysis of the results using the Spearmans test and the Kruskal Wallis test.

Results: A total of 31 cases included in this study, with Gleason grade group 5 accounting for almost half of the cases (41.94\%). Positive Her-2 expressions $(+1,+2,+3)$ were almost obtained in all samples (90.22\%), with Her-2 + 3 mostly found in grade group 5 (71.43\%). Positive Ki-67 expressions $(+1,+2,+3)$ were obtained in all samples, with $\mathrm{Ki}-67+3(>5 \%)$ in Gleason grade group 5 obtained in 5 samples (38.46\%). In the analysis of data by the Spearmans test, there was a positive correlation between the expression of Her-2 and Ki-67 with the Gleason Grade group. The Kruskal Wallis test found significant differences between the Ki-67 expressions and the Gleason Grade group.

Conclusion : Analysis of the expression of Her-2 and Ki-67 through immunohistochemical examination with the latest classification of the Gleason Grade group can be one of the prognostic parameters and management of therapy in prostate acinar adenocarcinoma.
\end{abstract}

Keywords: Prostate acinar adenocarcinoma, Her-2, Ki-67, Gleason grade group

\title{
PENDAHULUAN
}

Menurut Badan Internasional untuk Penelitian tentang Database GLOBOCAN 2012, kanker prostat juga merupakan penyebab utama kelima kematian akibat kanker pada pria.(1) Kanker prostat sendiri menyumbang sekitar $2 \%$ dari semua kematian terkait kanker di wilayah Asia-Pasifik pada tahun 2008.(2) Menurut Pusat Data Dan Informasi Kementerian Kesehatan RI tahun 2015, pravalensi kanker prostat di Indonesia tahun 2013 adalah sebesar 0,2\%o atau diperkirakan sebanyak 25.012 penderita.(3) Insidensi kanker prostat di berbagai wilayah meningkat secara signifikan. Fenomena tersebut dapat merupakan konsekuensi dari peningkatan skrining PSA, gaya hidup kebarat-baratan, aktivitas fisik yang kurang, dan peningkatan konsumsi lemak di masyarakat. Selain itu usia, genetik, riwayat keluarga, dan merokok, dapat pula menjadi faktor resiko yang menyebabkan terjadinya kanker prostat. $(2,4)$

Faktor resiko terbesar untuk kanker prostat adalah usia.(5) Sekitar 75\% laki-laki yang didiagnosis menderita kanker prostat berusia di atas 65 tahun.(6) Usia saja bukan merupakan faktor prognostik independen, dan masih menjadi kontroversi. Pembelajaran lebih lanjut diperlukan untuk pemahaman interaksi yang lebih baik antara usia dan faktor prognostik lainnya serta untuk mengidentifikasi faktor-faktor lain yang tidak diketahui. Petanda prognostik lainnya yang dapat digunakan yaitu seperti Gleason grade, stadium klinis dan PSA. 
Suatu Gleason grading system terbaru, yaitu grade group telah ditetapkan oleh ISUP di tahun 2014. Sistem ini menjadi salah satu parameter penting untuk menilai prognosis pasien dan keputusan pilihan tatalaksana kanker prostat termasuk operasi, radiasi dan yang membutuhkan pengawasan ketat. Gleason Grading System pada kanker prostat, umumnya diterapkan pada gambaran histopatologi adenokarsinoma. Adenokarsinoma konvensional menyumbang lebih dari $90 \%$ dari seluruh keganasan epitelial prostat. Secara umum, kanker prostat multifokal (terjadi pada 60-90\% kasus) akan memperlihatkan pola asinar atau asinar/duktal.(7)

Oleh karena petanda prognostik di atas memiliki nilai terbatas pada setiap individu, dibutuhkan pengembangan petanda prognostik molekuler untuk meningkatkan manajemen penderita kanker prostat. Salah satu perannya pada adenokarsinoma prostat yang masih belum jelas adalah Her-2 dan Ki-67. Her-2 adalah anggota reseptor tyrosine kinase. Overekspresi atau amplifikasi gen Her-2 dapat terjadi pada berbagai epitel tumor manusia, terutama pada kanker payudara, dimana reseptor dan gennya telah diteliti secara luas. Sebaliknya, pentingnya overekspresi Her-2 dan amplifikasi gen pada kanker prostat masih kontroversial. Ada yang menunjukkan hubungan antara ekspresi Her-2 dengan stadium lanjut dan grade yang lebih tinggi, namun ada pula yang sebaliknya. ${ }^{5}$ Ekspresi Her-2 telah dikaitkan dengan penyakit stadium lanjut, metastasis, kelangsungan hidup yang singkat, respon buruk terhadap kemoterapi, dan bahkan kegagalan terapi endokrin.(8)

Ekspresi protein Ki-67 manusia sangat terkait dengan proliferasi sel. Indeks Ki-67 lebih tinggi pada adenokarsinoma prostat daripada hiperplasia dan pada metastasis daripada kasus nonmetastatik, sehingga indeks Ki-67 yang meningkat mungkin menunjukkan prognosis penyakit yang buruk. Namun, perannya sebagai penanda prognostik independen di antara pasien dengan adenokarsinoma prostat masih kontroversial.(9)

Penelitian ini dilakukan untuk membuktikan ekspresi penanda tersebut pada adenokarsinoma asinar prostat dan kemungkinan hubungan dengan penilaian Gleason. Pertimbangan bukti korelasi antara penilaian Gleason grade group dengan prognosis kanker prostat, bersamaan dengan pemeriksaan Her-2 (proto-onkogen) dan Ki-67 (penanda proliferasi sel) diharapkan dapat menjadi salah satu parameter prognostik dan manajemen terapi yang tepat pada adenokarsinoma asinar prostat. 


\section{METODE PENELITIAN}

Penelitian ini adalah studi analitik observasional dengan desain cross-sectional. Sampel adalah pasien yang telah terdiagnosa sebagai adenokarsinoma asinar prostat, dalam bentuk blok parafin yang terfiksasi formalin dari Laboratorium Patologi Anatomik RSUP Dr. Kariadi, Semarang, Indonesia, sejumlah 31 blok, kemudian diklasifikasikan menurut kelompok Prognostik WHO / ISUP Gleason (Gleason Grade group 1 - 5) dalam periode waktu 1 Januari 2015 - 1 Januari 2018.

Data yang diambil meliputi: usia saat diagnosis yang kemudian dikategorikan ke dalam usia 41-50, 51-60, 61-70, 71-80 dan usia 81-90 tahun, lokasi tempat tinggal yaitu kota Semarang, kabupaten Semarang, Pati, Kendal, Salatiga, metastasis dan kadar PSA. Analisis data menggunakan SPSS Windows versi 17. Sebelum dilakukan uji hipotesis, data yang terkumpul terlebih dulu dilakukan proses editing, coding, entrying, dan cleaning data. Data yang berskala kategorikal dideskripsikan dalam bentuk jumlah dan prosentase, kemudian dilakukan uji kappa untuk menilai kesesuaian antara 2 pembaca, lalu analisa uji statistik non parametrik Kruskal Wallis untuk mengetahui perbedaan antara 2 variabel dan uji korelasi Spearmans untuk mengetahui hubungan antara 2 variabel, dengan nilai kemaknaan $p<0,05$.

\section{HASIL}

Penelitian ini menggunakan 31 sampel, didapatkan 13 (41.94\%) sampel yang termasuk dalam grade group 5, diikuti 7 sampel (22.58\%) untuk grade group 1, 4 sampel (12.90\%) untuk grade group 3 dan 4 , dan 3 (9.68\%) sampel yang termasuk grade group 2 .

Tabel 1. Karakteristik Pasien

\begin{tabular}{lll}
\hline Karakteristik Pasien & Jumlah & Prosentase \\
\hline Karakteristik Usia $(\mathrm{n}=31)$ & & \\
- $41-50$ & 1 & $3.23 \%$ \\
- $51-60$ & 3 & $9.68 \%$ \\
- $61-70$ & 16 & $51.61 \%$ \\
- $71-80$ & 8 & $25.81 \%$ \\
Karakteristik Tempat Tinggal & 3 & $9.68 \%$ \\
$(\mathrm{n}=31)$ & & \\
- Kota Semarang & 19 & $61.29 \%$ \\
- Kabupaten Semarang & 1 & $3.23 \%$ \\
- Pati & 5 & $16.13 \%$ \\
- Kendal & 4 & $12.90 \%$ \\
- Salatiga & 2 & $6.45 \%$
\end{tabular}


Grade Group ( $\mathrm{n}=31)$

- $1(3+3)$ 7

$22.58 \%$

- $2(3+4)$

3

$9.68 \%$

- $3(4+3)$

4

$12.90 \%$

- $4(4+4,3+5,5+3)$

4

$12.90 \%$

- $5(4+5,5+4,5+5)$

13

$41.94 \%$

Berdasarkan tabel (Tabel 1) diatas penderita adenokarsinoma prostat paling banyak ditemukan pada rentang usia 61-70 tahun, yaitu sebanyak 16 orang (51.61\%). Sedangkan pada rentang usia 41-50 tahun, hanya didapatkan 1 orang (3.23\%) pada usia 50 tahun. Didapatkan usia penderita diatas usia 80 tahun yaitu usia 83 tahun dan 88 tahun.

Keterangan tempat tinggal pasien digunakan untuk mempertimbangkan jarak antara tempat tinggal dengan rumah sakit yang memiliki pelayanan kesehatan lengkap sehingga dapat melakukan pemeriksaan skrining kanker prostat, dan pemeriksaan penunjang untuk kecurigaan metastasis selama follow up. Pada penelitian ini, pasien dominan tinggal di daerah perkotaan, yaitu kota Semarang, dengan jumlah 19 orang (61.29\%). Penderita yang tinggal di lokasi terjauh dari kota Semarang, yaitu kabupaten Pati, sebanyak 5 orang (16.13\%), dan lokasi terdekat, yaitu kabupaten Semarang, sebanyak 1 orang (3.23\%).

Data pasien dari 31 sampel, hanya didapatkan 17 sampel (54,84\%) yang memiliki data lengkap metastasis, 14 sampel lainnya $(45,16 \%)$ tidak mencantumkan data klinis, baik pemeriksaan kadar PSA pra dan pasca operasi, respon terapi, staging, serta pemeriksaan penunjang selama follow up.
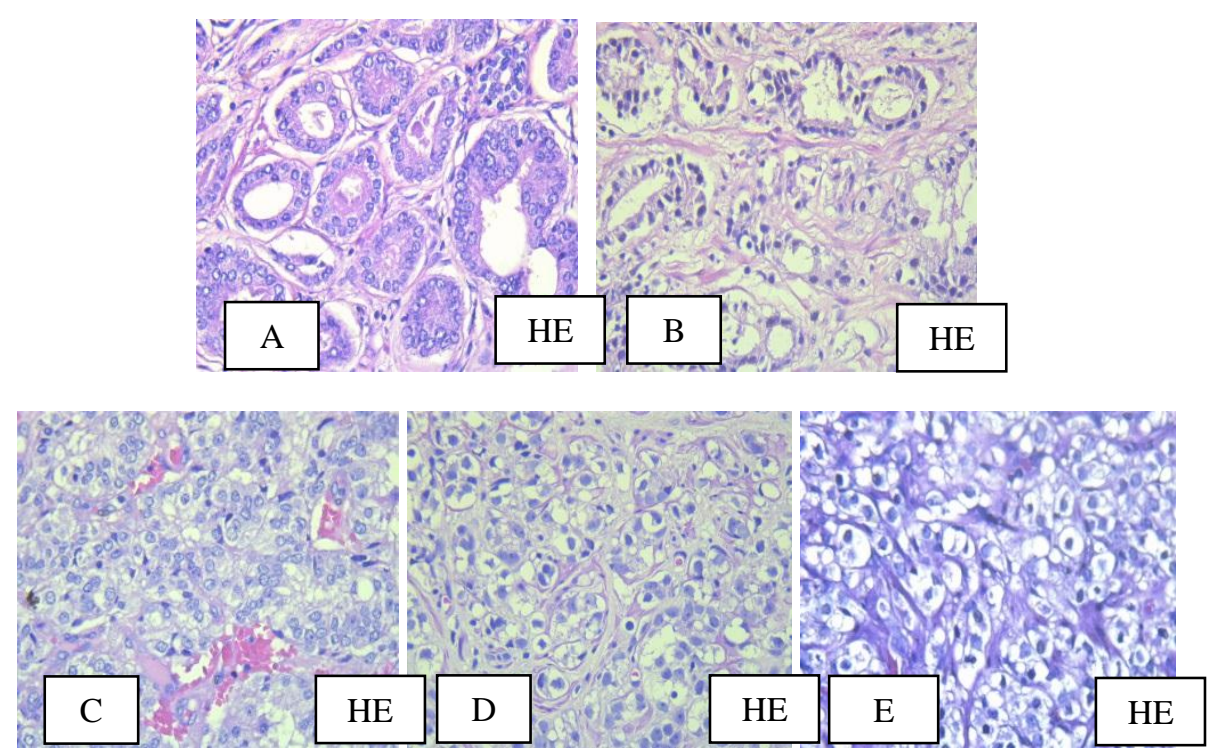

Gambar 1. Histopatologi adenokarsinoma prostat (HE, 100X): A. Grade group 1 (3+3). Hanya terdiri dari kelenjar individu yang terbentuk dengan baik; B. Grade group $2(3+4)$. Predominan kelenjar yang 
terbentuk dengan baik, dengan sedikit komponen cribriform, menyatu.; C. Grade grup $3(4+3)$.

Predominan kelenjar yang terbentuk buruk/ menyatu, dengan sedikit komponen yang terbentuk baik.

D. Grade group 4 (4+4). Hanya kelenjar yang terbentuk buruk / menyatu / cribriform, E. Grade group 5

$(5+5)$. Tidak ditemukan bentukan kelenjar.
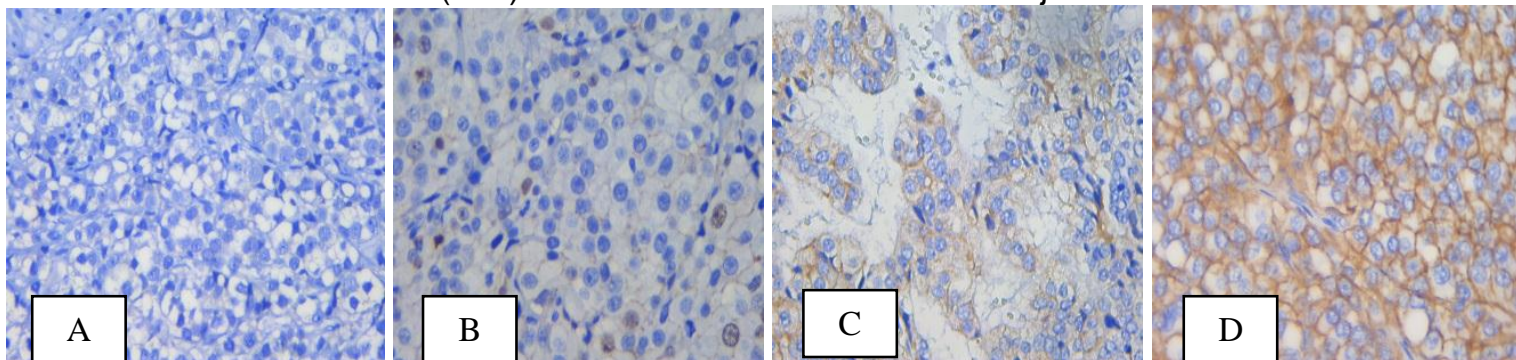

Gambar 2. Ekspresi Her-2 (400X): A. Skor (0) negatif. Tidak ada pewarnaan yang terlihat. B Skor (+) positif 1.Pewarnaan samar pada lebih dari $10 \%$ sel tumor. C. Skor $(++)$ positif 2 . Pewarnaan lemah sampai sedang, lebih dari $10 \%$ sel tumor. D. Skor $(+++)$ positif 3 . Pewarnaan kuat lebih dari $30 \%$ sel tumor.
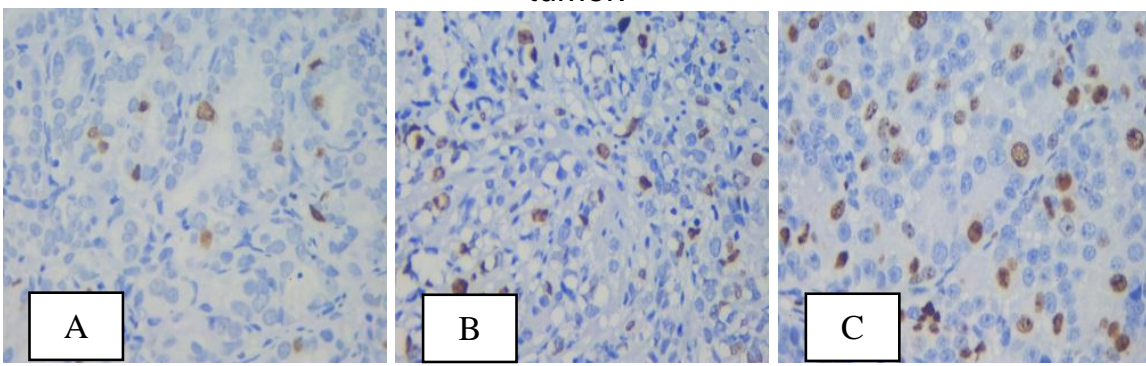

Gambar 3. Ekspresi Ki-67 : A. (+) positif 1. 1-2.5\%, (400x) B. (++) positif 2. 2.6-4\% (400x). C (+++) positif $3 . \geq 5 \%$. (400x).

\section{Uji Analisis}

Tabel 2. Hasil uji Kappa antara dua pembaca berdasarkan grade group

\begin{tabular}{cccc}
\hline Grade Group & Pembaca I & Pembaca II & K (\%) \\
\hline Negatif & 6 & 3 & $0,748(74,8 \%)$ \\
+1 & 16 & 25 & \\
+2 & 21 & 23 & \\
+3 & 19 & 11 & \\
\hline
\end{tabular}

Uji Kappa menunjukkan hasil yang sesuai antara pembaca pertama dan pembaca kedua.

Tabel 3. Hasil uji Kruskal Wallis ekspresi Her-2 dan Ki-67 terhadap grade group

\begin{tabular}{ccccccc}
\hline & \multicolumn{9}{c}{ Grade Group } & \multirow{2}{*}{} \\
\cline { 2 - 5 } & $\mathbf{1}$ & $\mathbf{2}$ & $\mathbf{3}$ & $\mathbf{4}$ & $\mathbf{5}$ & $\mathbf{0}$ \\
\hline $\begin{array}{c}\text { Ekspresi Her-2 } \\
\text { Negatif }\end{array}$ & 4 & 0 & 1 & 0 & 1 & 0,057 \\
+1 & 2 & 0 & 0 & 0 & 3 & \\
+2 & 1 & 2 & 3 & 2 & 3 & \\
+3 & 0 & 1 & 0 & 2 & 6 & \\
Ekspresi Ki-67 & & & & & & \\
+1 & 5 & 2 & 2 & 0 & 2 & $0,022^{*}$ \\
+2 & 2 & 1 & 0 & 1 & 6 & \\
+3 & 0 & 0 & 2 & 3 & 5 & \\
\hline
\end{tabular}

Keterangan * Signifikan $(p<0,05)$ 
Uji Kruskal Wallis untuk Her-2 menunjukkan adanya perbedaan ekspresi pada tiap grade, namun tidak bermakna. Pada Ki-67 didapatkan adanya perbedaan bermakna antara ekspresi Ki-67 dengan grade.

Tabel 4. Hasil uji korelasi Spearmans pada Her-2 dan Ki-67 terhadap grade group

\begin{tabular}{|c|c|c|c|c|c|c|}
\hline & \multicolumn{5}{|c|}{ Grade Group } & \multirow[b]{2}{*}{$\mathbf{p}$} \\
\hline & 1 & 2 & 3 & 4 & 5 & \\
\hline \multicolumn{7}{|l|}{ Ekspresi Her-2 } \\
\hline Negatif & 4 & 0 & 1 & 0 & 1 & $0,010^{*}$ \\
\hline+1 & 2 & 0 & 0 & 0 & 3 & \\
\hline+2 & 1 & 2 & 3 & 2 & 3 & \\
\hline+3 & 0 & 1 & 0 & 2 & 6 & \\
\hline \multicolumn{7}{|l|}{ Ekspresi Ki-67 } \\
\hline+1 & 5 & 2 & 2 & 0 & 2 & $0,007^{*}$ \\
\hline+2 & 2 & 1 & 0 & 1 & 6 & \\
\hline+3 & 0 & 0 & 2 & 3 & 5 & \\
\hline
\end{tabular}

Keterangan : ${ }^{*}$ Signifikan, positif, lemah

Uji Korelasi Spearmans, menunjukkan terdapat korelasi positif antara peningkatan ekspresi Her-2 dan Ki-67 dengan peningkatan Gleason grade group.

\section{DISKUSI}

Salah satu faktor resiko utama pada kanker prostat adalah usia, sekitar 75\% kanker prostat, terjadi pada usia di atas 65 tahun.(6) Rentang usia 61-70 tahun pada penelitian ini, menjadi yang paling dominan dengan jumlah 16 org (51.61\%) dengan usia rata-rata 66,56 . Sesuai dengan penelitian Mardiana et al, dengan usia rata-rata 64, 96 tahun dan Verma et, al, dengan usia rata-rata 69.98 tahun. $(9,10)$ Beberapa penelitian mengatakan bahwa onset penyakit pada usia muda, berhubungan dengan perilaku penyakit agresif, dan memiliki angka mortalitas yang lebih tinggi. Pada penelitian ini, didapatkan 1 pasien termuda dengan usia 50 tahun, dan menurut data rekam medis, pasien tersebut memiliki riwayat metastasis tulang. Usia paling tua didapatkan pada pasien usia 88 tahun, tidak didapatkan adanya metastasis pada pasien tersebut. Pembelajaran lebih lanjut diperlukan untuk pemahaman interaksi yang lebih baik antara usia dan faktor prognostik lainnya serta untuk mengidentifikasi faktor-faktor lain yang tidak diketahui.

Karakteristik tempat tinggal pasien dikelompokan berdasarkan jarak antara Kota Semarang yang memiliki fasilitas kesehatan lengkap dengan kabupaten yang berdekatan di sekitarnya. Didapatkan 19 pasien (61.29\%) yang bertempat tinggal di wilayah kota Semarang. Untuk kabupaten yang paling dekat $(22 \mathrm{~km})$ dengan Kota Semarang, yaitu Kabupaten Semarang, didapatkan 1 orang 
pasien, disertai metastasis, kadar PSA pra operasi $>100 \mathrm{ng} / \mathrm{ml}$, dan pasca operasi $0,74 \mathrm{ng} / \mathrm{ml}$. Dan kabupaten terjauh $(75 \mathrm{~km}$ ),yaitu kabupaten Pati sebanyak 5 orang pada pasien ini pula 1 orang didapatkan dengan metastasis, dan nilai PSA pra operasi $>100 \mathrm{ng} / \mathrm{ml}$, pasca operasi tidak dicantumkan, sedangkan 4 sisanya, data rekam medis kosong tanpa riwayat klinis sebelumnya.Menurut Dasgupta et, al, menemukan bukti yang konsisten untuk ketidaksetaraan geografis di berbagai indikator kanker prostat di berbagai populasi, dengan pasien dari daerah tertinggal menghadapi beban kanker prostat yang lebih tinggi.(11) Meskipun ada beberapa bukti hubungan antara tempat tinggal di pedesaan dan beban kanker prostat yang lebih tinggi, namun polanya kurang konsisten. Zahnd et, al, mengungkapkan hal ini dapat disebabkan oleh karena faktor kemiskinan, merokok, dan kurangnya skrining kanker. Secara spesifik, penderita dari daerah pedesaan dan daerah tertinggal secara sosial ekonomi, memiliki tingkat yang lebih rendah pada tes skrining PSA, insidensi penyakit, kelangsungan hidup, dan akses untuk penggunaan pelayanan kesehatan, oleh karena itu pasien datang dengan penyakit yang lebih agresif dan tingkat kematian yang lebih tinggi.(12)

Pada penelitian ini, dari 31 sampel, didapatkan sebagian besar sampel 13 (41.94\%) sampel termasuk dalam grade group 5, Pertemuan konsensus internasional pada akhir tahun 2014, di Chicago Amerika Serikat, Pertemuan tersebut dilakukan oleh ISUP dalam menanggapi dan mengatasi masalah yang tidak terselesaikan atau tidak tercakup dalam konsensus 2005. Perkembangan paling penting dari pertemuan tersebut adalah contoh sistem pengelompokan kelas prognostik baru, yang mungkin berdampak besar pada ahli patologi dan klinisi, disebut dengan Grade Group. Pada penelitian kohort Offermann et al, membuktikan bahwa pada sampel radikal prostatektomi tidak mendapatkan adanya kegunaan prognosis dengan menggunakan Grade Group, dibandingkan dengan Gleason Grading yang lama. Namun, insiden peningkatan dari biopsi ke radikal prostatektomi yang sesuai, lebih rendah dengan menggunakan grade group, membuktikan bahwa penggunaan sistem baru dapat meningkatkan prediksi yang akurat pada jaringan biopsi.(13) Pada penelitian Kohort Erickson et al, menyimpulkan bahwa sistem baru grade group, layak untuk memprediksi kelangsungan hidup setelah terapi bedah.(14) Grade Group menawarkan cara sederhana untuk memprediksi perjalanan penyakit pasien secara individu sehingga dapat membantu tindak lanjut yang lebih konservatif pada pasien dengan grade group rendah. 
Dari 17 data rekam medis yang ditemukan, pasien yang mengalami metastasis ditemukan sejumlah 9 pasien yang hampir seluruhnya (66,67\%) memiliki Grade group 5. Menurut penelitian Yamada et, al, mereka menemukan bahwa pasien kanker prostat dengan metastasis tulang yang memiliki gleason score 9-10 (Grade group 5) memiliki outcome yang lebih buruk dibandingkan dengan yang memiliki gleason score 8 (Grade group 4).(15) Pola histopatologi juga berperan pada progresifitas adenokarsinoma prostat, pada penelitian Liang Cheng et al, pola hitopatologi 4 dan 5 dikaitkan dengan usia yang lebih tua, kadar PSA pra operasi yang lebih tinggi, grade patologi yang lebih tinggi, batas sayatan bedah yang positif, ekstensi tumor ekstraprostatik, skor Gleason yang lebih tinggi, invasi perineural, dan metastasis kelenjar getah bening.(16)

Data ekspresi Her-2 terhadap grade group menggunakan uji perbedaan Kruskal Wallis, menunjukkan nilai yang tidak signifikan, dan analisis data dengan uji korelasi Spearmans, menunjukkan korelasi positif antara peningkatan ekspresi Her-2 dengan peningkatan grade group. Hal ini berbeda dengan penelitian yang pernah dilakukan, seperti penelitian Nishio et, al. Penelitian tersebut menyatakan bahwa tidak ada perbedaan signifikan pada kadar PSA, stadium penyakit yang lebih luas, Gleason score, T-stage, atau N-stage antara Her-2 positif dan Her-2 negatif. Namun, penelitian ini mendapatkan bahwa tingkat ketahanan hidup spesifik 5 tahun, secara signifikan lebih rendah pada Her-2 positif dibandingkan dengan Her-2 negatif, tingkat non-rekurensi 3 tahun pada Her-2 positif juga lebih rendah dibandingkan dengan Her-2 negatif.(17) Senada dengan Kalantari et al, yang juga menggunakan klasifikasi grade group pada penelitiannya, tidak ditemukan adanya korelasi yang signifikan antara ekspresi Her-2 dengan gleason score.(18)

Beberapa penelitian menunjukkan hasil yang berbeda, berkaitan dengan hubungan ekspresi Her-2 dengan Gleason grading system. Pada penelitian Signoretti et, al, menunjukkan ekspresi Her-2 lebih tinggi pada pasien dengan terapi ablasi androgen total, dibandingkan dengan pasien dengan terapi bedah saja, begitupun ekspresi yang di dapatkan pada pasien gagal terapi ablasi androgen lebih tinggi dibandingkan pada pasien yang diterapi bedah saja. Selain itu, penelitian ini menyatakan adanya hubungan ekspresi Her-2 positif dengan Gleason grade yang lebih tinggi.(19) Hal yang sama didapatkan pada penelitian Ross et, al. mengungkapkan adanya hubungan antara overekspesi Her-2 dengan tumor grade.(20)

Dari penjelasan di atas dapat menjadi salah pertimbangan bahwa pada pasien adenokarsinoma prostat dengan overekspresi Her-2, dapat berkaitan dengan dengan status bebas 
androgen. Tanpa adanya androgen, overekspresi Her-2 mengaktifkan transkripsi PSA. Aktivasi PSA yang dimediasi Her-2 membutuhkan AR yang tidak dihambat oleh obat antiandrogen. Dengan demikian, ekspresi berlebih Her-2 dalam sel kanker prostat mengaktifkan jalur AR tanpa adanya ligan, menstimulasi kemandirian androgen dari sel kanker prostat. Her-2 awalnya menyebabkan kelangsungan hidup sel-sel tumor dengan mengaktifkan jalur AR dengan cara yang bebas androgen. Namun, sel-sel yang sama ini mungkin masih membutuhkan androgen untuk proliferasi. Hipotesis ini didukung oleh pengamatan bahwa, meskipun sebagian besar sel sekretori mengalami apoptosis setelah penarikan androgen, sisa sel sekretori yang dipertahankan dalam prostat menunjukkan kadar protein Her-2 yang tinggi. Peningkatan ekspresi Her-2, diduga menjadi spesifik-prostat daripada mekanisme khusus-tumor untuk kelangsungan hidup sel pada lingkungan yang kekurangan androgen.(19)

Mengenai hubungan metastasis dengan ekspesi Her-2, pada penelitian ini didapatkan sebagian data berkaitan dengan kejadian metastasis, ekspresi Her-2 dengan nilai positif ditemukan pada semua sampel metastasis. +1 berjumlah 1 pasien, +2 berjumlah 5 pasien, +3 berjumlah 3 pasien. Menurut Murray et, al, setidaknya $85 \%$ pria dengan penyakit lanjut akan mengalami metastasis tulang, dengan peningkatan jumlah pasien bebas metastasis pada saat pengobatan awal ternyata memiliki mikrometastasis tersembunyi. Selanjutnya, $30 \%$ hingga $50 \%$ pria dengan kanker prostat terlokalisir akan mengalami kegagalan biokimia dengan peningkatan PSA pada tahun ke10.(21) Hal ini terjadi karena penyebaran sel kanker pada awal penyakit tidak terdeteksi dengan metode konvensional. Sel-sel kanker menyebar pertama kali ke struktur neurovaskular, kemudian ke darah. Dari sana mereka berpindah ke jaringan lain dengan melewati endotel kapiler, menginvasi, serta membentuk mikrometastasis. Invasi tumor dianggap sebagai aktivitas fisiologis yang tidak dapat diatur, dengan kesamaan antara peristiwa molekuler invasi tumor dan proses normal seperti angiogenesis dan penyembuhan luka.(21) Morote et, al. yang menggunakan 70 pasien adenokarsinoma disertai metastasis, melaporkan adanya overekspresi sebesar $64 \%$ pada pasien adenokarsinoma prostat dengan metastasis. Namun tidak ada perbedaan yang signifikan, berkaitan dengan Gleason score atau ekspresi Her-2, baik pada metastasis tulang atau di luar tulang.(22) Nishio et, al, berpendapat bahwa overekspresi Her-2 pada pasien kanker prostat dengan metastasis tulang dapat menjadi penanda prognosis buruk untuk memprediksi interval rekurensi dan outcome setelah terapi endokrin. (17) 
Perbedaan penelitian ini dengan beberapa penelitian lain, dapat disebabkan karena beberapa faktor, yatu pertama, jumlah sampel yang digunakan, pada penelitian yang menyatakan adanya hubungan antara ekspresi Her-2 dengan sistem penilaian Gleason, hubungan dengan metastasis, serta kaitannya dengan status bebas androgen, jumlah sampel yang digunakan lebih besar dengan data yang lebih lengkap, waktu penelitian yang lebih panjang, dan prosentase grade group tinggi (grade group 5) lebih banyak dibandingkan pada penelitian yang memberikan hasil sebaliknya. Kedua, prosedur bedah dalam pengambilan sampel, penelitian dengan teknik pengambilan radikal prostatektomi, memberikan hasil yang lebih signifikan dibandingkan dengan pengambilan dengan biopsi atau sediaan TURP. Selain itu, jaringan yang terkena kauter minimal, sehingga pengecatan imunistokimia dapat lebih optimal. Ketiga, pengumpulan data rekam medis termasuk riwayat terapi pasien, keterangan metastasis pada sampel, kadar PSA pra dan pasca operasi yang tidak lengkap, keterangan bergantung atau bebas androgen pada pasien, juga dapat mempengaruhi hasil, semakin lengkap data yang didapat, semakin mudah pula analisa berbagai faktor lain yang berhubungan dengan overekspresi Her-2 dan penilaian Gleason. Keempat, faktor ras dan pengaruh faktor genetik, diketahui ras Afrika-Amerika, menyumbang ras terbesar pada resiko adenokarsinoma prostat,hal ini dipengaruhi oleh beberapa faktor, salah satunya adalah pengaruh genetik. Rebeck, mengungkapkan bahwa adanya beberapa perubahan genetik pada ras Afrika Amerika tidak didapatkan pada ras Eropa dan Asia.(23) Magi-Galluzzi et, al melaporkan bahwa frekuensi translokasi TMPRSS2: ERG paling tinggi di Jepang (71\%) dan Kaukasia (62\%) dan jauh lebih rendah di Afrika Amerika (20\%).(24) Hal tersebut membutuhkan penelitian lebih lanjut, karena selain faktor ras dan genetik, faktor lingkungan, perilaku dan faktor lainnya sangat berpengaruh pada kejadian adenokarsinoma prostat.

Analisa data ekspresi Ki-67 terhadap grade dengan uji perbedaan Kruskal Wallis menunjukkan perbedaan yang bermakna dan uji korelasi Spearmans, menunjukkan adanya hubungan antara peningkatan ekspresi Ki-67 dan peningkatan grade group. Hal ini sesuai dengan penelitian yang pernah dilakukan, seperti penelitian Richardsen et, al membuktikan adanya hubungan antara peningkatan ekspresi Ki-67 dengan Gleason grade, ukuran tumor, dan pT stage.(25) Studi yang dilakukan oleh Verma et, al, menyatakan bahwa adanya korelasi antara Ki-67 dengan Gleason grade, dengan $\mathrm{p}$ value 0,002, dikatakan bahwa tiap 1\% peningkatan dari kadar Ki-67 yang dihubungkan dengan Gleason Score berhubungan dengan 12\% peningkatan kematian berkaitan dengan prognosis.(9) Pada penelitian kohort Fisher et, al, yang bertujuan untuk melihat nilai prognosis Ki-67 
terhadap kematian akibat kanker prostat, pada analisis univariat didapatkan Gleason score, PSA, penyakit yang meluas, usia saat didiagnosa, dan skor Ki-67, merupakan prediktor yang signifikan untuk kematian akibat kanker prostat. (26)

Hal ini sesuai dengan teori yang menyatakan bahwa, penanda proliferasi Ki-67 memperlihatkan proliferasi sel tumor, yang berhubungan dengan progresi, metastasis, dan prognosis pada beberapa keganasan. Ki-67 merupakan protein regulasi yang berkaitan dengan siklus sel pada inti, dan ekspresinya dapat dideteksi selama interfase pada inti di sel epitelial tumor (G1, S, G2, dan mitosis), dan tidak ditemukan pada sel istirahat (G0), karenanya menjadikan Ki-67 penanda yang sangat baik untuk menilai fraksi pertumbuhan tumor.(27)

Pada penelitian ini, ekspresi Ki-67 dengan nilai $(+)$ positif $(+1,+2,+3)$ ditemukan pada semua sampel metastasis. Studi oleh Diaconescu et, al, membuktikan bahwa ekspresi Ki-67 sebagai marker proliferasi memiliki nilai prediktif pada pasien pasien kanker prostat dengan metastasis kelenjar getah bening ini dibuktikan dengan adanya perbedaan sangat signifikan ekspresi Ki-67 antara tumor primer tanpa metastasis dengan tumor primer dengan metastasis kelenjar getah bening, walaupun ada pula yang mendapatkan hasil sebaliknya seperti penelitian Vis et, al mendapatkan adanya kesesuaian dan sensitifitas yang rendah untuk ekspresi Ki-67 sebagai prognosis agresifitas penyakit.(28)

Perbedaan diatas dapat disebabkan karena beberapa faktor, penelitian yang memberikan hasil signifikan, menggunakan sampel dari sediaan radikal prostatektomi, sehingga area yang diperiksa untuk melihat indeks proliferasi sel tumor lebih besar. Pada penelitian yang memberikan hasil sebaliknya, menggunakan biopsi jarum, dan hanya 1-2 core yang diperiksa sehingga tidak mewakili tumor primer, selain itu pola heterogen dari adenokarsinoma prostat, sehingga menyulitkan untuk dianalisa, karena bercampur dengan kelenjar normal atau lesi jinak. Penyebab lainnya adalah belum ada cut off point yang standar untuk menilai ekspresi Ki-67, sehingga sulit untuk menetapkan standar tinggi rendahnya kadar Ki-67 pada kanker prostat. Fisher et, al mengungkapkan bahwa cut off point $10 \%$ lebih bermakna dibandingkan dengan $5 \%$, dalam hal prognosis kematian, dan rekurensi biokimia.(26) 


\section{KESIMPULAN}

Analisa ekspresi Her-2 dan Ki-67 melalui pemeriksaan imunohistokimia dengan klasifikasi terbaru

Gleason Grade group dapat menjadi salah satu parameter prognosis dan manajemen terapi pada adenokarsinoma asinar prostat.

Ucapan Terima Kasih

Instalasi Laboratorium Patologi Anatomik RSUP Dr. Kariadi dan Bagian Patologi Anatomik FK Undip.

\section{DAFTAR PUSTAKA}

1. Braga-Basaria M, Dobs A, Muller D, Carducci M, John M, Egan J, et al. Metabolic syndrome in men with prostate cancer undergoing long-term androgen-deprivation therapy. J Clin Oncol. 2006;3979-3983.

2. Baade PD, Youlden DR, Krnjacki LJ. International epidemiology of prostate cancer: Geographical distribution and secular trends. Mol Nutr Food Res. 2009;53(2):171-84.

3. Penyakit Kanker S. InfoDATIN 4 Februari-Hari Kanker Sedunia [Internet]. [cited 2019 Jul 16]. Available from: http://www.depkes.go.id/resources/download/pusdatin/infodatin/infodatinkanker.pdf

4. Taitt HE. Global Trends and Prostate Cancer: A Review of Incidence, Detection, and Mortality as Influenced by Race, Ethnicity, and Geographic Location. Am J Mens Health. 2018;12(6):1807-23.

5. World Health Organization. Pathology and Genetics of Tumours of the Urinary System and Male Genital Organs. World Health Organization Classification of Tumours. 2016. 138-162 p.

6. Goldblum JR, Lamps LW, McKenney JK, Myers JL. ROSAI AND ACKERMAN'S SURGICAL PATHOLOGY 11TH EDITION. 11th ed. Philadelphia: Elsevier; 2018. 1494 p.

7. Ro JY, Shen S, Zhai Q, Ayala A. ADVANCES IN SURGICAL PATHOLOGY PROSTATE CANCER. Cagle P, Allen T, editors. Philadelphia: Wolters Kluwer Health | Lippincott Williams \& Wilkins; 2012. 4 p.

8. Sharifi N, Salmaninejad A, Ferdosi S, Bajestani AN, Khaleghiyan M, Estiar MA, et al. HER2 gene amplification in patients with prostate cancer: Evaluating a $\mathrm{CISH}$-based method. Oncol Lett [Internet]. 2016 Dec [cited 2018 Sep 8];12(6):4651-8. Available from: https://www.spandidos-publications.com/10.3892/ol.2016.5235

9. Verma R, Gupta V, Jagjeet S, Monica V, Gopal G, Gupta S, et al. Significance of p53 and ki-67 expression in prostate cancer. Urol Ann [Internet]. 2015;4:488-493. Available from: https://www.ncbi.nlm.nih.gov/pmc/articles/PMC4660702/

10. Mardiana N, Susilo I. Hubungan Ekspresi Her-2 / Neu , Skor Gleason dan Metastasis Tulang pada Adenokarsinoma Prostat. 2012;22(2):45-50.

11. Dasgupta P, Baade PD, Aitken JF, Ralph N, Chambers SK, Dunn J. Geographical Variations in Prostate Cancer Outcomes: A Systematic Review of International Evidence. Front Oncol [Internet]. 2019 Apr 8 [cited 2019 Jul 9];9:238. Available from: https://www.frontiersin.org/article/10.3389/fonc.2019.00238/full

12. Zahnd WE, James AS, Jenkins WD, Izadi SR, Fogleman AJ, David ; et al. Rural-Urban Differences in Cancer Incidence and Trends in the United States. 2017 [cited 2019 Jul 9]; Available from: http://cebp.aacrjournals.org/content/cebp/early/2017/07/27/1055-9965.EPI-170430.full.pdf

13. Offermann A, Hohensteiner S, Kuempers C, Ribbat-Idel J, Schneider F, Becker F, et al. Prognostic Value of the New Prostate Cancer International Society of Urological Pathology Grade Groups. Front Med [Internet]. 2017 Sep 29 [cited 2019 Jul 27];4:157. Available from: http://journal.frontiersin.org/article/10.3389/fmed.2017.00157/full

14. Erickson A, Sandeman K, Lahdensuo K, Taimen P, Rannikko A, Mirtti T. New prostate cancer grade grouping system predicts survival after radical prostatectomy is. Hum Pathol [Internet]. 2018;75:159-66. Available from: https://doi.org/10.1016/j.humpath.2018.01.027

15. Yamada Y, Sakamoto S, Shimazaki J, Sugiura M, Amiya Y, Sasaki M, et al. Significant prognostic difference between Grade Group 4 and 5 in the 2014 International Society of Urological Pathology Grading System for High Grade Prostate Cancer with Bone Metastasis. 
Prostate Int [Internet]. 2017;5(4):143-8. Available from: https://doi.org/10.1016/j.prnil.2017.03.001

16. Cheng L, Davidson DD, Lin H, Koch MO. Percentage of Gleason Pattern 4 and 5 Predicts Survival After Radical Prostatectomy. 2007;(September):6-11.

17. Nishio Y, Yamada Y, Kokubo H, Nakamura K, Aoki S, Taki T, et al. Prognostic significance of immunohistochemical expression of the HER-2/neu oncoprotein in bone metastatic prostate cancer. Urology. 2006;68(1):110-5.

18. Kalantari MR, Mahdavi Zafarghandi R, Tavakkoli M, Kalantari S, Aghaee A, Mirsani A, et al. Relation between HER-2 gene expression and prognostic prostate cancer parameters in trus guided biopsies. J Patient Saf Qual Improv. 2019;7(2):69-74.

19. Signoretti S. Her-2-neu Expression and Progression Toward Androgen Independence in Human Prostate Cancer. J Natl Cancer Inst. 2000;92(23):1918-25.

20. Ross JS, Sheehan CE, Hayner-Buchan AM, Ambros RA, Kallakury BVS, Kaufman RP, et al. Prognostic significance of HER-2/neu gene amplification status by fluorescence in situ hybridization of prostate carcinoma. Cancer. 1997;79(11):2162-70.

21. Murray NP, Reyes E, Tapia P, Badínez L, Orellana N. Differential Expression of Matrix Metalloproteinase-2 Expression in Disseminated Tumor Cells and Micrometastasis in Bone Marrow of Patients with Nonmetastatic and Metastatic Prostate Cancer: Theoretical Considerations and Clinical Implications—An Immunocy. Bone Marrow Res. 2012;2012:1-9.

22. Morote J, De Torres I, Caceres C, Vallejo C, Schwartz S, Reventos J. Prognostic value of immunohistochemical expression of the c-erbB-2 oncoprotein in metastasic prostate cancer. Int J Cancer. 1999;84(4):421-5.

23. Rebbeck TR. Prostate Cancer Genetics: Variation by Race, Ethnicity, and Geography. [cited 2019 Jul 28]; Available from: www.ebi.ac.uk/gwas/

24. Magi-Galluzzi C, Tsusuki T, Elson P, Simmerman K, LaFargue C, Esgueva R, et al. TMPRSS2-ERG gene fusion prevalence and class are significantly different in prostate cancer of caucasian, african-american and japanese patients. Prostate [Internet]. 2011 Apr [cited 2019 Jul 28];71(5):489-97. Available from: http://doi.wiley.com/10.1002/pros.21265

25. Richardsen E, Andersen S, Al-Saad S, Rakaee M, Nordby Y, Pedersen MI, et al. Evaluation of the proliferation marker Ki-67 in a large prostatectomy cohort. PLoS One. 2017;12(11).

26. Fisher G, Yang ZH, Kudahetti S, Møller H, Scardino P, Cuzick J, et al. Prognostic value of Ki67 for prostate cancer death in a conservatively managed cohort. Br J Cancer. 2013;2:271-7.

27. Tan PH, Bay BH, Yip G, Selvarajan S, Tan P, Wu J, et al. Immunohistochemical detection of Ki67 in breast cancer correlates with transcriptional regulation of genes related to apoptosis and cell death. Mod Pathol. 2005;18(3):374-81.

28. Vis AN, Van Rhijn BWG, Noordzij MA, Schröder FH, Van Der Kwast TH. Value of tissue markers p27kip1, MIB-1, and CD44s for the pre-operative prediction of tumour features in screen-detected prostate cancer. J Pathol. 2002;197(2):148-54. 